\title{
ENERGY SECURITY: THE IMPACT OF ENVIRONMENTAL POLICIES ON ENERGY SECURITY
}

Summary: Extreme climatic events, global warming, biodiversity loss, ozone depletion, water, air and soil pollution, major accidents have made the issues of environmental change in the environment and the impact on environmental insecurity has become the center of security analysis.The notion of energy security is constantly changing, as is the attitude towards the complex strategic activities that they entail. National security strategies did not include environmental security considerations until the end of the Cold War. Population growth, globalization and general technological and economic progress have led to a drastic increase in natural resources, the provision of energy sources to supply the economy and citizens is on the map of the most important geostrategic and geopolitical issues. Climate change and the issue of environmental protection have posed new challenges for the energy sector. Energy is the basis of modern life, from heating the household to driving a car, which is why its provision is vital for any national security.

Keywords: energy security, environment, energy, renewable energy.

* Faculty of Law, Univerzitet Megatrend, Beograd, Srbija; home.vitosevic@gmail.com

** Faculty of Law, University Union; Belgrade, Serbia; mario.lukinovic@pravnifakultet.rs

*** Department of Landscape Management, Faculty of Forestry and Wood Technology, Brno, Czech Republic; lefong@lefong.sk 


\section{Introduction}

From the end of the 18th century until today, economic development is directly related to the use of various types of energy, influencing economic growth and the decline of economies. "Without energy, there is no life," she said, driving everything from photosynthesis to spaceflight. Therefore, the normal functioning and progress of any society depends on energy, and changes in the flow of energy in any of its fields cause changes in all other subsystems. Although energy resources make up only about $5 \%$ of the output of economic values, 95\% depend on energy input. ${ }^{2}$ As economies became more complex, the need for energy grew, realizing that wood was becoming insufficient to adequately support the growth of economies, humanity turned to hydropower, then to coal, and then to oil and natural gas, and finally to nuclear energy. ${ }^{3}$ Energy consumption is constantly increasing, especially that derived from fossil fuels. Exponential population growth and technological advances are leading to a surge in energy demand.

Disposal of natural resources (land, forests, water, wildlife) has played a key role in the social and economic progress of mankind. The industrial revolution changed the everyday life of people, based on Zimmerman's phrase "resources exist only when we use them" and the observation that they should be used as intensively as possible in order to achieve the greatest possible economic benefits. ${ }^{4}$ Extensive use of natural resources, especially "non-renewable natural resources" (oil, coal, natural gas) and their exploitation, which is always accompanied by negative effects such as pollution, resource depletion, etc. which necessarily leads to a crisis.

\section{The energy security and impact on environmental systems}

Although many authors cite environmental risks as potentially devastating to the planet, the planet is not really in danger. Even if there are consequences that could jeopardize the biological survival of humans on the planet, it will continue its life without humans, in a similar way as it continued after the disappearance of the dinosaurs. A healthy environment is actually a condition for humans and certain plant and animal species. When environmental pollution

1 Proroković, D., Kilibarda, Z., (2015): „Nastajanje geopolitičkih žarišta u naftnim zonama“, Vojno delo, LXVII, br. 4/2015, p. 18.

2 Harris, J. M., (2009): Ekonomija životne sredine i prirodnih resursa: Savremeni pristup, Data Status, Beograd, p. 279.

Ibid.

Milutinović, S., (2020): Upravljanje prirodnim resursima, Fakultet zaštite na radu u Nišu, p. 97. 
reaches a stage where pollution exceeds its capacity for self-regulation and there is a "likelihood of loss of life and health or property due to exposure to environmental hazards", ${ }^{5}$ then we are talking about environmental crises. Threats to environmental security have a different character from changes in the living conditions of man and society, through the depletion of natural resources to environmental disasters and the consequences they bring with them. ${ }^{6}$

The most common risk factors are:

- devastation of ecosystems (climate change, loss of biodiversity, ozone depletion, soil erosion, flooding, desertification, deforestation, etc.);

- population problems (birth rate, population density, migration, epidemics, nutrition problem, etc.);

- depletion of natural resources (ores and minerals / coal, oil, natural gas; water, flora and fauna);

- environmental pollution (pollutants that have harmful effects on soil, water, air, flora and fauna);

- energy problems;

- physical security of infrastructure and stability of deliveries (natural disasters, technical disruption, terrorist acts or political decisions) ${ }^{7}$

Impacts that endanger plant and animal fauna can be abiotic (physico-chemical environmental conditions: climatic, edaphic and orographic factors) and biotic (interrelationships and influence of living beings) of which the humananthropogenic factor is the most destructive. ${ }^{8}$

The energy sector participates with $73 \%$ of human-caused greenhouse gas emissions, making it a major factor in climate change.

Environmental degradation leads to changes in the environment (drought, desertification, deforestation) that result in conflicts and migrations from the environment affected by such phenomena. Climate and environmental changes have affected human migration since the inception of human labor, but with the establishment of territorial boundaries such movements have become more difficult. ${ }^{9}$ Due to that, the appearance of the so-called ecological refugees was observed only in 1995 when it was noticed that at least 25 million "people are

Bošković, M., (2017): Leksikon bezbednosti, JP Službeni glasnik/Pravni fakultet Univerziteta u Novom Sadu, Centar za izdavačku delatnost, Beograd-Novi Sad, p. 194.

6 Ibid.

7 Aleksić, J., Adžemović, M., (2015): Ekološka bezbednost, Primenjena ekologija: vodič, Beograd: Fakultet za primenjenu ekologiju Futura : Green Limes, pp. 265-273.

8 Bošković, M., (2017): Leksikon bezbednosti, JP Službeni glasnik/Pravni fakultet Univerziteta u Novom Sadu, Centar za izdavačku delatnost, Beograd-Novi Sad, p. 195.

$9 \quad$ Nesseef, L., (2018): Političke posledice migracija izazvanih ekološkim katastrofama, Fakultet političkih nauka, Univerzitet u Beogradu, p. 10. 
no longer able to ensure a safe life in the country of origin due to large-scale environmental factors such as drought, desertification, deforestation, soil erosion, water scarcity, climate changes, as well as natural disasters in the form of cyclones, storms and floods."10 According to certain estimates, between 2008 and 2016, 227.6 million people were displaced due to natural disasters, while in 2017 alone, 18.8 million people in 135 countries were displaced due to sudden disasters. ${ }^{11}$ These data show us that more people have been displaced due to natural disasters at the global level than due to armed conflicts and wars.

Unlike the traditional concept of security, which was focused exclusively on issues related to national security, the modern model has gone beyond the research field. Linking security matters to different types of challenges, risks and threats has led to the view that "risks can manifest themselves in different ways". "Human security is the latest in a long line of neologisms that encourages politicians and researchers to understand international security as something broader than the military defense of state interests and territory." ${ }^{\prime 3}$ The task of the society is to ensure the safety of the ecosystem from critical threats or actions through a system of preventive measures, in order to ensure space and conditions for human life. The basic function of any security system is prevention, which eliminates the cause of danger and achieves the desired state. ${ }^{14}$ The system of these preventive measures consists of social, legal, technical, medical and bilogical measures. ${ }^{15}$

Climate change also affects the prevalence and behavior of vectors of infectious diseases. The prevalence of many parasitic protozoa is directly correlated with temperature, as are worms and bacteria that enjoy heat and humidity. Due to climate change, there are fears that malaria could return to parts of the planet where it is temperate. The distribution and amount of the virus is influenced by

10 Myers, N., Kent, J., (1995): „Environmental Exodus: an Emergent Crisis in the Global Arena", Climate Institute, Washington DC, according to: Šekarič, N., Stojanović, F., (2018): „Ekološke izbeglice - (ne) rešiv problem međunarodne zajednice“, Vojno delo, 3/2018, pp. 38-54.

11 Todić, D., (2019): „Izbeglice i promene u životnoj sredini u međunarodnom pravu“, Strani pravni život, 63/2019, Issue No: 3, pp. 5-16.

12 Orlić, D., (2004): Pojmovno određenje izazova, rizika i pretnji u procesu preoblikovanja međunarodne bezbednosti, Vojno delo, 3/04, p. 84. according to: Ilić, P., (2013): Bezbednosni izazovi, rizici i pretnje ili činioci ugrožavanja bezbednosti, Pravne teme, Godina 1, br. 2, p. 52-61.

13 Paris, R., (2001) : „Human Security - Paradigm Shift or Hot Air?“, International Security, Vol. 26. no 2., pp. 87 - 102. according to prema: Lipovac. M., Glušac, L., (2011): „Perspektive koncepta ljudske bezbednosti“, Kultura polisa, VIII (2011), br. 16, p. 57-76.

14 Labović, D. (2015): Privatna bezbednost: pravna i socijalna dimenzija, Inovacioni centar fakulteta bezbednosti, p. 34 .

15 Bošković, M., (2017): Leksikon bezbednosti, JP Službeni glasnik/Pravni fakultet Univerziteta u Novom Sadu, Centar za izdavačku delatnost, Beograd-Novi Sad, p. 195. 
biological conditions such as vegetation, as well as physical conditions such as precipitation, humidity, wind, etc. ${ }^{16}$

The attention of political and security circles was first drawn to environmental security issues by the pessimistic predictions of Robert Kaplan, who warned in 1994 that "it is time to understand the environment as it is: the issue of national security at the beginning of the twenty-first century." The political impact of population waves, the spread of disease, the destruction of rainforests and soil erosion, water consumption, air pollution and possible sea level rise ... will encourage mass migration and ignite the spark of group conflict - it will be the core of the foreign policy challenge. public and unifying interests left over from the Cold War." ${ }^{\prime 7}$

Climate change caused by anthropological action is affecting human health, reducing food production, the availability of water sources, increasing poverty and the accelerated extinction of plant and animal species. ${ }^{18}$ Anthropogenic factors have a great influence on changes in the environment. Depletion and depletion of the ozone layer, environmental pollution, devastation of nature, extinction of plant and animal species. Human impact causes changes in the geological environment, leaving consequences and impact on all ecosystems: lithosphere, hydrosphere, biosphere and atmosphere. ${ }^{19}$ Combustion of fossil fuels and their derivatives releases energy, leading to pollution that leads to a global pollution effect. Directly or indirectly, fossil fuels pollute the environment, from exploitation, through processing to their consumption. ${ }^{20}$

By polluting nature, man poisons himself, because through the food chain, the products of that pollution end up on his table, causing many diseases. ${ }^{21}$ The correlation between climate change and human health is confirmed by the first

16 Radna grupa za zaštitu prirode pri naučnom univerzitetu „Etves Lorand“, (2011): „Klimatske promene i zdravlje ljudi“, in: Beogradske perspektive održivog razvoja i klimatskih promena, Međunarodni naučni forum „Dunav - reka saradnje“, Beograd, p. 141169.

17 Kaplan, R. (1994): „The coming anarchy“, The Atlantic Monthly, 273(2), pp. 44-76. according to: Dalby, S., (2012): Promena životne sredine, Uvod u studije bezbednosti, Službeni glasnik/ Fakultet bezbednosti Univerzitet u Beogradu, p. 345.

18 Lukinović, M., Jovanović, Đ., Jovanović, L., (2016): „Borba protiv klimatskih promena i analiza rezultata konferencije u Parizu“, Međunarodna naučna konferencija Ekološka kriza: tehnogeneza i klimatske promene, pp.153 -160.

19 Stevanović, B., et. al. (2003):Enciklopedija - životna sredina i održivi razvoj, IP Ecolibri/ Zavod za udžbenike i nastavna sredstva Srpsko Sarajevo, Beograd, p.116.

20 Aksentijević, S., Đuričić, M., Milutinović, S., (2006): „Unapređenje sistema životne sredine zagađene fosilnim gorivima“, in: Festival kvaliteta 2006, 1. Nacionalna konferencija o kvalitetu života, Agencija za kvalitet i standardizaciju Srbije, Centar za kvalitet Kragujevac, Kragujevac, pp. 49- 54.

21 Lukinović, M., Jovanović, L., Milovanović, S., (2017): „Globalni sporazum gradonačelnika za klimu, energiju: „Najveća svetska inicijativa za urbanu klimu i energiju“, Ecologica, Naučno-stručno društvo za zaštitu životne sredine, br. 03/2017, pp. 54-59. 
official diagnosis according to which the patient suffers from "climate change". Dr Kyle Merritt cited climate change as the cause of a patient's health problems, whose general health was negatively affected by poor air quality in British Columbia due to extreme heat waves and thick smog caused by strong fires. ${ }^{22}$

Technological progress is largely linked to energy consumption, bringing the economies of many countries into a position of dependence on energy. The price of energy is influenced by numerous factors, of which the usual ratio of supply and demand is only one of the factors. And a number of risks significantly affect the price. Technological risks are present from the initial research, through the exploitation of energy sources all the way to their transport to the end users. Financial risks occur due to the large amplitude of energy prices. Regional instabilities, military interventions, political crises and social turmoil have the most pronounced impact on world energy prices. In recent years, the fight against climate change has conditioned the price of energy, especially due to the intention to reduce the consumption of fossil fuels. ${ }^{23}$

\section{Energy security}

The first significant energy crisis occurred in 1973, when OPEC members, together with several Arab countries, stopped supplying oil to the United States, protesting against the country's policy towards the regional conflict, which led to an almost fourfold increase in world oil prices. Thus, for the first time, it came to the point that countries that have energy resources are in a position to influence the economies of energy importing countries through energy.After that, the issue of energy security began to be studied within the framework of the consideration of international relations and became the main topic of strategic debates. ${ }^{24}$ The struggle for supremacy and influence on the world political scene is less and less oriented towards military power, and more and more towards strategic and economic development, bringing "energy diplomacy" into the focus of events. ${ }^{25}$ The strategic function of the state is to ensure the normal functioning of the economic system and economic conditions for a conflict-free situation, as

$22 \quad$ Mishra, S., Canadian becomes world's first patient to be diagnosed as suffering from 'climate change', Indipendent, available at: https://www.independent.co.uk/climate-change/ news/canada-climate-change-diagnoses-patient-b1953355.html, visited: 09.11.2021.

23 Nosić, A., Karasalihović, Sedlar, D., Jukić, L., (2017): „Terminska i opcijska tržišta ugljikvodonika“, Rudarsko-geološko-naftni zbornik, 32 (4), pp. 54-54.

24 Trapara, V., Šekarić, N., (2019): „Saradnja kao (ne)očekivan efekat energetske bezbednosne dileme: studija slučaja Bugarske, Grčke i Jugoslavije“, Međunarodni problemi, Institut za međunarodnu politiku i privredu, God. 71, br. 2, pp. 215-243.

25 Glamotchak, M. (2015): „Energetska zavisnost Zapadne Evrope: uspon i pad“,Međunarodni problemi, Vol. 67. Issue 4, p. 279-303. 
well as to possibly eliminate potential economic uncertainty ${ }^{26}$ that increasingly depends on energy factors.

The price of energy on the world market is increasingly conditioned by a multitude of different interests, where political factors usually prevail over economic ones and which is very sensitive to geopolitical turmoil. Due to different perspectives of observing the concept of energy security, its understanding is very uneven. From the point of view according to which it is an extended aspect of national security, through the perception according to which it is linked to individual security, to perceptions based on risk assessments and environmental protection.For countries that export energy, the vision of energy security is directed towards "security of demand": orderly payment of energy, security of energy infrastructure, etc. ${ }^{27}$ The devastation of nature and the problems that come with climate change and environmental disturbances lead to cumulative social effects that also have security implications. Human well-being and well-being are affected by environmental degradation and depletion of natural resources, causing population movements, declining economies and weakening states. Therefore, the issue of sustainable development is increasingly a central issue of political, economic and other processes. Sustainable development is a path of economic and social development that does not jeopardize the chances for the development of future generations. ${ }^{28}$

Energy security, as defined by the International Energy Agency, is "the uninterrupted physical availability of energy at an affordable price, while respecting the environment." 29 This definition connects several determinants. The issue of security of energy supply is complex and the importance of the numerous authors are equating its importance with energy security, ignoring environmental, social and other aspects. Regardless of its importance, it is not possible to consider this notion without understanding the well-being of citizens and environmental parameters. ${ }^{30}$

The population in the XX. century increased 3.7 times, while the demand for final energy increased more than 30 times. $^{31}$ Stable supply of energy to the

26 Bošković, M., (2017): Leksikon bezbednosti, JP Službeni glasnik/Pravni fakultet Univerziteta u Novom Sadu, Centar za izdavačku delatnost, Beograd-Novi Sad, p. 195.

27 Ljuština. A., (2012): Ekološka bezbednost, Kriminalističko-policijska akademija, Beograd, p. 13.

28 Kuper, A., Kuper, Dž., (2009): Enciklopedija društvenih nauka, Službeni glasnik, tom I, p. 233.

29 According to: Trapara, V., Šekarić, N., (2019): „Preispitivanje energetske bezbednosne dileme, Energetska diplomatija Republike Srbije u savremenim međunarodnim odnosima“,Institut za medunarodnu politiku i privredu, pp. 33-49.

30 Radovanović, M., (2019): Energetska bezbednost, Univerzitet Educons, Sremska Kamenica, p. 49.

31 Jovanović, L., Radović, V., Lukinović, M., (2018):,Significance of energy efficiency for energy security", Fundamental and applied researches in practice of leading scientific schools, 28(4), 46-52. 
extent that it ensures the normal functioning of the economy. The availability of energy is important for the realization of any economic state policy, but also an issue that is crucial for national security. ${ }^{32}$ Preservation of the energy system and its resistance to disturbances in the supply and price of energy.Energy as an area of economy that deals with the production and distribution of energy and energy sources is becoming one of the central global issues. ${ }^{33}$ The energy market is specific and different from other markets, among other things, mostly because it implies a networked infrastructure of distribution, transport and transmission networks. ${ }^{34}$ Population growth and global economic activity have increased the need for energy in the world.

Part of the global agreements the idea that the share of coal in the total energy balance should be reduced the share of coal in the total energy balance will decline.

Ensuring the energy security of the state is an obligatory item in the foreign policy agenda of all modern states. A stable supply of energy for the purpose of continuous growth has also become a matter of national security. ${ }^{35}$ The importance of this issue is largely conditioned by the foreign policy and its positioning of countries on the political map of the world.

Hunger for energy is unlikely to lead to the ultimate depletion of energy resources, but it will certainly increase their price, and that will complicate some of the security risks.

\section{Energy transition in the $21^{\text {st }}$ century towards sustainability}

In the $20^{\text {th }}$ and $21^{\text {st }}$ century GHG emissions have grown significantly in our atmosphere as a result of increasing fossil fuel consumption all around the globe. Rapid demand of fossil fuel over last hundred years is associated with economic development and global trade. For instance, automotive industry has experienced enormous expansion; nowadays, our generation is privileged to use all possible means of transportation to reach any corner of the world in relatively short period of time. It was not a reality of our ancestors one hundred years ago.

\footnotetext{
32 Proroković, D., (2019): „Geopolitički kontekst energetske bezbednosti“, Međunarodni problemi, Institut za međunarodnu politiku i privredu, Vol. LXXII, br. 1, pp. 254-273.

33 T. Janić, M. Brkić, S. Igić, N. Dedović, (2010): Biomasa - energetski resurs za budućnost. Savremena poljoprivredna tehnika, Vojvođansko društvo za poljoprivrednu tehniku, 36(2), p. 167-177.

34 V. Čavrak, T. Gelo, D. Pripužić, (2006): „Politika cijena u energetskom sektoru i utjecaj cijena energenata na gospodarski razvoj Republike Hrvatske“, Zbornik Ekonomskog fakulteta u Zagrebu, godina 4. pp. 45-68.

35 Proroković, D., (2019): „Energetska bezbednost SAD i političko pozicioniranje Srbije“, in:Energetska diplomatija Republike Srbije u savremenim medunarodnim odnosima, Institut za međunarodnu politiku i privredu, Beograd, pp. 114-134.
} 
Previous organic farming in the villages has shifted towards monoculture farming based on using chemicals (additives of petroleum and CO2) in order to feed the growing population.

Western society has been enjoying high living standards and consumption life, while societies on the South have been struggling for their existence. Due to excessive use of materials, energy sources and unlimited exploitation of natural resources, our generation is facing many ecological problems- ocean, river, air and soil pollution...

Today, scientists warn our humanity to reduce consumption of fossil fuels and coal that leave significant footprint in our nature and may lead to ecological disaster. In 2050 , more than $70 \%$ of the world population will live in the cities, which will cause a great pressure for energy demand. On one hand, we have to control unsustainable extraction of finite natural resources, on the other hand, we have to reduce dependency on petroleum, coal and oil, by promotion of alternative sources of low-carbon energy.

Energy transition towards "carbon-free" energy sources is a structural change in energy system. ${ }^{36}$ International society is engaging in low-carbon development and environmental protection through various multinational treaties and deals. For instance, the Paris Agreement is a legally binding international treaty on climate change. ${ }^{37}$ Global leaders are putting their efforts to tackle climate change and safeguard food and energy security; the recent UN Climate Change Conference in Glasgow has proven their intentions. European Union presented a plan based on European Green Deal to become "carbon-neutral" society by 2050 . EU aims to reduce greenhouse gas emissions by at least $55 \%$ by 2030 that requires higher shares of renewable energy and greater energy efficiency. China itself has pledged to become carbon neutral nation by 2060 .

Energy transition from fossil fuels towards renewables is deeply connected to circular economy. In March 2020 the European Commission presented, under the European Green Deal and in line with a proposed new industrial strategy, the new circular economy action plan that includes proposals on more sustainable product design, reducing waste and empowering consumers (such as a right to repair). Specific focus is brought to resource intensive sectors, such as electronics and ICT, plastics, textiles and construction. ${ }^{38}$

Circular economy is a pathway to a low-carbon future. This concept promises to restore and replace old materials, which will eliminate the waste through recycling process (reuse, repair, remanufacture). Proper waste management will be needed and old structure is going to be completely redefined. Society will

\footnotetext{
36 Okafor, Ch., et al. (2021):,,Situating coupled circular economy and energy transition in an emerging economy“,AIMS Press, p. 655.

37 https://unfccc.int/process-and-meetings/the-paris-agreement/the-paris-agreemen

38 https://www.europarl.europa.eu/news/en/headlines/economy/20151201STO05603/circular-economy-definition-importance-and-benefits
} 
shift towards renewable energy design; fossil fuel energy will be converted to solar, wind and hydro power energy. Circular economy framework optimizes use of resources for energy production, therefore ensures reduction in energy consumption and its ecological footprint.

To reach net zero emissions by 2050, annual clean energy investment worldwide will need to more than triple by 2030 to around $\$ 4$ trillion. This will create millions of new jobs, significantly lift global economic growth, and achieve universal access to electricity and clean cooking worldwide by the end of the decade. ${ }^{39}$ Material conservation and sustainable development involves new methods of business, energy transition, deployment of sustainable products and innovative technology. Circular economy will definitely lead towards changes in consumer's behavior.

\section{From fossil fuels to renewable energy sources}

At this moment, renewables are getting more investment than ever, which has to do with global call for carbon emissions reduction. Covid-19 has shifted investment away from fossil fuels; oil prices experienced its total drop as a result of lockdown policies all around the globe. In that period, people stayed at home, stopped using cars or aviation transportation. Global energy demand in 2020 fell by $4 \%$, the largest decline since World War II and the largest ever absolute decline. ${ }^{40}$ The value of shares in the energy market dropped by $40 \%$ (oil and gas companies), while photovoltaic solar collector producers and wind turbine factories have doubled its share.

Wind and solar farms depend on geographical location and weather conditions. The coefficient of annual efficiency of wind power varies between $15-50 \%$, while highest rates can be obtained in offshore areas, where wind power is stronger than inner land. Efficiency rate of wind power on shore is $15-30 \%{ }^{41}$

Renewables require not only access to specific areas where they are installed (being very limited in the countries with high-density populations), but production of high- tech electronic components (solar panels, rechargeable batteries, wind turbines) require supply of specific rare materials mined in large quantities around the globe. Demand for precious materials has been growing exponentially. Chart 1 shows the future predictions and demand for rare materials by 2050, such as silver, praseodymium, terbium, etc.

\footnotetext{
39 https://www.iea.org/reports/net-zero-by-2050

40 https://www.iea.org/reports/global-energy-review-2021/economic-impacts-of-covid-19

${ }^{41}$ Vondra, A., ed.,(2020):Musí být ekonomie alarmistická ? Hledání realistických odpovědí. Books \& Pipes. ISBN: 978-80-7485-217-6, p.190.
} 


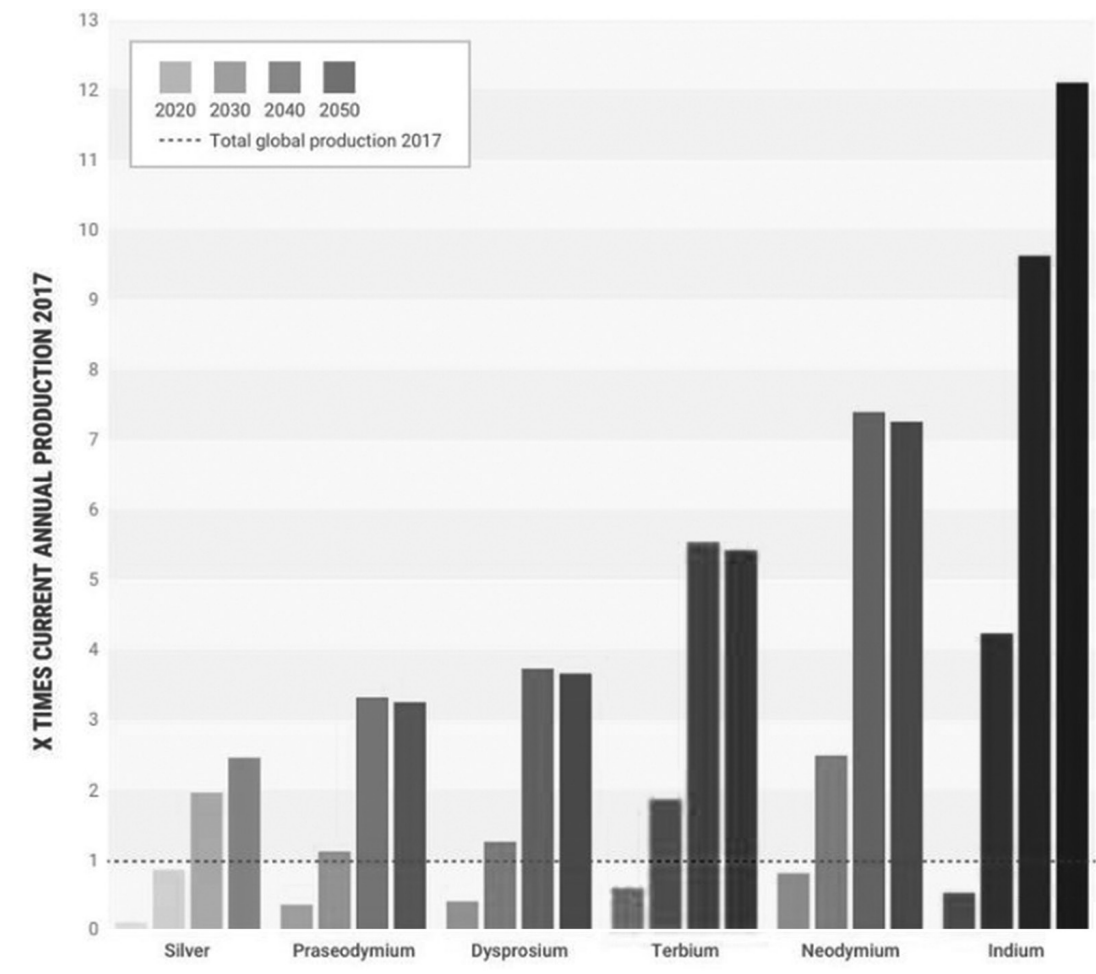

Source: www.popularmechanics.com/science/energy/a25576543/renewable-limits-materials-dutchministry-infrastructure/

\section{Chart 1. Total global production.}

Nuclear energy represents another form of low-carbon energy source. It is very stable and highly efficient source of energy. In 2019, nuclear reactors produced 2676 TWh of electricity around the globe, which was the highest rate during the era of nuclear power plants. This amount represented $10,2 \%$ of total electricity amount being produced, which equals $1 / 3$ of low-carbon electricity being produced in Europe. Over the recent years, nuclear power plants in EU produce $40-50 \%$ of low-carbon electricity. ${ }^{42}$

Proposed energy transformation plan to achieve efficient and clean energy consumption which will completely replace use of fossil fuels, coal and gas is quite unpredictable. We have critical segments that need constant electricity supply such as hospitals, food-processing factories, metallurgical plants which require continuous cycle of smelting, etc. At this moment, EU doesn't have capacities when the expected demand exceeds the supply capable of being generated by clean power. Moreover, there has to be further research to develop large-scale batteries, which are able to store renewable energy when weather conditions are

$42 \quad$ Ibid. 
unfavorable. EU countries will continue finding themselves dealing with similar situations. The storage capacity needed to resolve the issue isn't expected to be installed in the EU until the latter half of this decade. ${ }^{43}$

\section{Conclusion}

Until the end of the Cold War, environmental security issues were not included innational security strategies. Population growth, globalization and general technological and economic progress have led to a drastic increase in the consumption of natural resources. Interstate conflicts over the claim to energy sources, population migration caused by environmental problems, are challenges for individual and national security that have led to changes in the understanding of the concept of energy security and attitudes towards complex strategic activities that they involve

Practice has shown that regulatory (legal) measures are not sufficient in themselves. The devastation of nature leads to changes that inevitably lead to the question of the survival of the human population and the ruin of civilization. In order to reach the required level, an efficient, safe and sustainable systemic arrangement is necessary, which implies a different economic, technological, social and cultural social model.

In order to ensure the creation of a safe environment for present and future generations, a universal transition to sustainable development is necessary, primarily in the energy related policies of states.

The perspective of energy security is also conditioned by the perspective of the state from which it is viewed. Although it predominantly refers to the provision of a sufficient amount of energy needed to meet vital needs, as most countries must resort to energy imports to meet those needs, it has long since moved into the field of foreign policy. ${ }^{44}$ Also, the increasing pressure to reduce the use of fossil fuels gives it a new meaning related to the strategies of switching from energy sources that cause climate change to green energy sources. In order to insure countries against restrictions on the use of fossil fuels, many are opting to create to create stocks.

Recognizing that it is necessary to put environmental threats on national security agendas is an important step towards changing the current situation.

\footnotetext{
43 https://www.eia.gov/todayinenergy/detail.php?id=49876

44 Kler, M. (201): Energetska bezbednost, Uvod u studije bezbednosti, Službeni glasnik/ Fakultet bezbednosti Univerzitet u Beogradu, p. 608.
} 


\section{Literature:}

- Aksentijević, S., Đuričić, M., Milutinović, S., (2006): „Unapređenje sistema životne sredine zagađene fosilnim gorivima", in: Festival kvaliteta 2006, 1. Nacionalna konferencija o kvalitetu života, Agencija za kvalitet i standardizaciju Srbije, Centar za kvalitet Kragujevac, Kragujevac, pp. 49- 54.

- Aleksić, J., Adžemović, M., (2015): Ekološka bezbednost, Primenjena ekologija: vodič , Beograd: Fakultet za primenjenu ekologiju Futura: Green Limes, pp. 265-273.

- Bošković, M., (2017): Leksikon bezbednosti, JP Službeni glasnik/Pravni fakultet Univerziteta u Novom Sadu, Centar za izdavačku delatnost, Beograd-Novi Sad, p. 194.

- Dalby, S., (2012): Promena životne sredine, Uvod u studije bezbednosti, Službeni glasnik/ Fakultet bezbednosti Univerzitet u Beogradu, p. 345.

- Glamotchak, M. (2015): „Energetska zavisnost Zapadne Evrope: uspon i pad“, Međunarodni problemi, Vol. 67. Issue 4, p. 279-303.

- Harris, J. M., (2009): Ekonomija životne sredine i prirodnih resursa: Savremeni pristup, Data Status, Beograd, p. 279.

- https://unfccc.int/process-and-meetings/the-paris-agreement/the-parisagreemen

- https://www.europarl.europa.eu/news/en/headlines/ economy/20151201STO05603/circular-economy-definition-importanceand-benefits

- https://www.iea.org/reports/global-energy-review-2021/economic-impactsof-covid-19

- https://www.iea.org/reports/net-zero-by-2050

- Ilić, P., (2013): „Bezbednosni izazovi, rizici i pretnje ili činioci ugrožavanja bezbednosti“, Pravne teme, Godina 1, br. 2, p. 52-61.

- Jovanović, L., Radović, V., Lukinović, M., (2018): „Significance of energy efficiency for energy security", Fundamental and applied researches in practice of leading scientific schools, 28(4), pp. 46-52.

- Kaplan, R. (1994): „The coming anarchy“, The Atlantic Monthly, 273(2), pp. 44-76.

- Kler, M. (201): Energetska bezbednost, Uvod u studije bezbednosti, Službeni glasnik/ Fakultet bezbednosti Univerzitet u Beogradu, p. 608.

- Kuper, A., Kuper, Dž., (2009): Enciklopedija društvenih nauka, Službeni glasnik, tom I, p. 233.

- Labović, D. (2015): Privatna bezbednost: pravna i socijalna dimenzija, Inovacioni centar fakulteta bezbednosti, p. 34 .

- Lipovac. M., Glušac, L., (2011): „Perspektive koncepta ljudske bezbednosti“, Kultura polisa, god. VIII (2011), br. 16, p. 57-76. 
- Lukinović, M., Jovanović, Đ., Jovanović, L., (2016): „Borba protiv klimatskih promena i analiza rezultata konferencije u Parizu“, Međunarodna naučna konferencija Ekološka kriza: tehnogeneza i klimatske promene, pp. 153 -160.

- Lukinović, M., Jovanović, L., Milovanović, S., (2017): „Globalni sporazum gradonačelnika za klimu, energiju: „Najveća svetska inicijativa za urbanu klimu i energiju“, Ecologica, Naučno-stručno društvo za zaštitu životne sredine, br. 03/2017, pp. 54-59.

- Ljuština. A., (2012): Ekološka bezbednost, Kriminalističko-policijska akademija, Beograd, p. 13.

- Milutinović, S., (2020): Upravljanje prirodnim resursima, Fakultet zaštite na radu u Nišu, p. 97.

- Mishra, S., „Canadian becomes world's first patient to be diagnosed as suffering from 'climate change'“, Indipendent, available at: https://www.independent.co.uk/climate-change/news/canada-climate-change-diagnoses-patientb1953355.html, posećeno: 09.11.2021.

- Myers, N., Kent, J., (1995): Environmental Exodus: an Emergent Crisis in the Global Arena, Climate Institute, Washington DC.

- Nesseef, L., (2018): Političke posledice migracija izazvanih ekološkim katastrofama, Fakultet političkih nauka, Univerzitet u Beogradu, p. 10.

- Nosić, A., Karasalihović, Sedlar, D., Jukić, L., (2017): „Terminska i opcijska tržišta ugljikvodonika“, Rudarsko-geološko-naftni zbornik, 32 (4), pp. 54-54.

- Okafor, Ch., et al. (2021): Situating coupled circular economy and energy transition in an emerging economy. AIMS Press, p. 655.

- Orlić, D., (2004):„Pojmovno određenje izazova, rizika i pretnji u procesu preoblikovanja međunarodne bezbednosti“, Vojno delo, 3/04, p. 84.

- Paris, R., (2001): Human Security - Paradigm Shift or Hot Air?, International Security, Vol. 26. no 2., pp. 87 - 102.

- Proroković, D., (2019): „Energetska bezbednost SAD i političko pozicioniranje Srbije“, in: Energetska diplomatija Republike Srbije u savremenim međunarodnim odnosima, Institut za medunarodnu politiku i privredu, Beograd, pp. 114-134.

- Proroković, D., (2019): „Geopolitički kontekst energetske bezbednosti“, Međunarodni problemi, Institut za međunarodnu politiku i privredu, Vol. LXXII, br. 1, pp. 254-273.

- Proroković, D., Kilibarda, Z., (2015): Nastajanje geopolitičkih žarišta u naftnim zonama", Vojno delo, god. LXVII, br. 4/2015, p. 18.

- Radna grupa za zaštitu prirode pri naučnom univerzitetu „Etves Lorand“, (2011): „Klimatske promene i zdravlje ljudi, Beogradske perspektive održivog razvoja i klimatskih promena“, Međunarodni naučni forum „Dunav reka saradnje“, Beograd, p. 141-169.

- Radovanović, M., (2019): Energetska bezbednost, Univerzitet Educons, Sremska Kamenica, p. 49. 
- Stevanović, B., et. al. (2003): Enciklopedija - životna sredina i održivi razvoj, IP Ecolibri/Zavod za udžbenike i nastavna sredstva Srpsko Sarajevo, Beograd, p. 116.

- S Sekarič, N., Stojanović, F., (2018): Ekološke izbeglice - (ne) rešiv problem međunarodne zajednice, Vojno delo, 3/2018, pp. 38-54.

- T. Janić, M. Brkić, S. Igić, N. Dedović, (2010): „Biomasa - energetski resurs za budućnost“,Savremena poljoprivredna tehnika, Vojvođansko društvo za poljoprivrednu tehniku, 36(2), p. 167-177.

- Todić, D., (2019): „Izbeglice i promene u životnoj sredini u međunarodnom pravu“, Strani pravni život, Institut za uporedno pravo, 63/2019, Issue No: 3, pp. 5-16.

- Trapara, V., Šekarić, N., (2019): „Preispitivanje energetske bezbednosne dileme“, in: Energetska diplomatija Republike Srbije u savremenim međunarodnim odnosima, Institut za međunarodnu politiku i privredu, pp. 33-49.

- Trapara, V., Šekarić, N., (2019): „Saradnja kao (ne)očekivan efekat energetske bezbednosne dileme: studija slučaja Bugarske, Grčke i Jugoslavije“, Međunarodni problemi, Institut za međunarodnu politiku i privredu, God. 71, br. 2, pp. 215-243.

- V. Čavrak, T. Gelo, D. Pripužić, (2006): „Politika cijena u energetskom sektoru i utjecaj cijena energenata na gospodarski razvoj Republike Hrvatske“, Zbornik Ekonomskog fakulteta u Zagrebu, God. 4. pp. 45-68.

- Vondra, A., ed., (2020): Musí být ekonomie alarmistická ? Hledání realistických odpovědí. Books \& Pipes. ISBN: 978-80-7485-217-6, p.190. 


\section{ENERGETSKA BEZBEDNOST: UTICAJ POLITIKA ŽIVOTNE SREDINE NA ENERGETSKU BEZBEDNOST}

Sažetak: Ekstremne klimatske pojave, globalno zagrevanje, gubitak biodiverziteta, smanjenje ozonskog omotača, zagadenju vode, vazduha i zemljišta, veliki akcidenti uticali su da pitanja ekoloških promena u životnoj sredini i uticaja na ekološku nesigurnost, postanu centar bezbednosnih analiza. Poimanje energetske bezbednosti kontinuirano se menja kao i odnos prema kompleksnim strategijskim aktivnostima koje one podrazumevaju. U strategijama nacionalnih bezbednosti sve do okončanja Hladnog rata nisu bila uključena razmatranja o ekološkoj bezbednosti. Porast broja stanovnika, globalizacija i opšti tehnološki i privredni napredak doveli su do drastičnog povećanja za prirodnim resursima, osiguravanje energetskih izvora za snabdevanje privrede i građanstva našlo se na mapi najvažnijih geostrateških i geopolitičkih pitanja. Klimatske promene i pitanje očuvanje životne sredine postavile su nove izazove za energetski sektor. Energija čini osnov savremenog života, od grejanja domaćinstva do vožnje automobilom, zbog toga je njeno obezbeđivanje od vitalnog značaja za svaku nacionalnu bezbednost.

Ključne reči: energetska bezbednost, životna sredina, energija, obnovljivi izvori. 